\title{
Changes in Job Tenure and Job Stability in Canada*
}

\author{
by Andrew Heisz
}

No. 95

11F0019MPE No. 95
ISSN:1200-5223
ISBN: 0-660-16578-3

Price: $\$ 5.00$ per issue, $\$ 25.00$ annually

Business and Labour Market Studies

24-E R.H. Coats Building, Ottawa, K1A 0T6

Statistics Canada (613) 951-3748

Facsimile Number: (613) 951-5403

November 1996

* This is a revised version of Heisz (1995), a paper presented to the Canadian Economics Association meetings held at the UQAM in June 1995. A summarized version of this paper was published as Heisz (1996). I would like to thank Miles Corak and Jean Kimmel for their helpful comments.

This paper represents the views of the author and does not necessavily reflect the opinions of Statistics Canada. 



\section{Table of Contents}

Table of Contents

iii

Abstract

$\mathbf{v}$

Introduction

1

Measuring Job Length and Stability 1

Changes in Job Stability 6

Polarization of Jobs, A Closer Look 7

Older Workers and Long Lasting Jobs 14

Conclusion 16

Bibliography 17 



\section{Abstract}

Using monthly data from the Canadian Labour Force Survey the author investigates changes in the complete lengths of new job spells from 1981 through 1994. While the average complete length of new jobs did not increase or decrease over the period, changes in the distribution of complete job lengths suggest that there is an increase in the proportion of short-term jobs and a decrease in the proportion of medium-term jobs created over the period. The proportion of long-term jobs remained unchanged. This pattem of change was found among virtually all demographic subgroups examined suggesting that an economy wide (rather than a sectoral or demographic) explanation must be sought.

Key Words: Job Tenure, Job Stability, Polarization. 



\section{Introduction}

It is widely thought that steady long-term employment is becoming less common. This perception may not be unfounded. Many labour analysts believe that employers are tailoning jobs in response to fluctuations in demand, with the result that offers of long-term employment are on the decline. They argue that firms are increasingly using a core of full time skilled employees and hire contingent workers when the demand arises. This is important because changes in the length of a job, or job tenure, affects the welfare of workers. In a long job, a worker has more chance to build up job skills, reach a high wage and access career advancement opportunities. Short jobs expose workers to more spells of unemployment, make it more difficult to accumulate a pension, and increase the need for mid-career retraining. ${ }^{1}$

This paper addresses the question of changing job tenure in Canada by asking: is job instability on the rise? are short-term jobs becoming more common? are long-term or "lifetime" jobs becoming less common? and if so for whom? This is done through estimating the average complete length of a new job over the period 1981 to 1994 . To the extent that the average job created over the period has become longer or shorter, it may be said that we have more or less job stability. It is also possible that the frequency of short and long jobs could change leaving the average length of jobs unchanged. Thus, the distribution of complete job lengths from 1981 to 1994 is also examined.

Most of the literature has worked either with measures of job tenure which were inappropriate for the study of changes in job stability, or with changes in the stability of relatively long jobs of four or more years in length. This study contributes to the literature on job tenure in at least three ways. First, it introduces a complete job length statistic which can be used to provide insights to the study of job stability in Canada and elsewhere. Second, it is the first study to examine changes in Canadian job tenure directly via changes in job suvival functions. Third, the study is unique in its detailed characterization of the survival function, particularly for jobs of short tenure. This makes it possible to assess the importance of changes in short- and medium-term jobs in understanding job stability.

\section{Measuring Job Length and Stability}

Researchers have identified at least three fundamentally different ways to measure the length of job spells. These can be described with reference to Hasan and de Broucker (1985) (Table 1). The first, which we call the interrupted length of in-progress jobs, describes the length of an ongoing job up to the date at which it was observed by a cross sectional survey. Clearly, this measure does not give the complete length of a job, but only the amount of time the job has lasted up to the date of the survey. The spell is truncated, or right censored: a job sampled in such a way may last many more years, or may end the next day. This is the measure most commonly made available by statistical agencies including Statistics Canada and the U.S. Bureau of Labor Statistics. Although it does not report the complete length of spells, this measure is useful for describing the tenure experience of

\footnotetext{
1 Changes in job stability should be placed in the context of other changes in the economy. These include the rise in non-standard work documented in the Economic Council of Canada (1991) and Christofides and McKenna (1995), the rise in eamings inequality in Picot, Myles and Wannell (1990) and Morissette, Myles and Picot (1993), and the case study evidence discussed in Osberg, Wein and Grude (1995) of the increasing use by firms of a core of permanent employees supplemented by short-term workers when required.
} 
the currently employed. Hasan and de Broucker reported this statistic as 7.4 years for 1980 using Canadian data.

Table 1

Alternate Measures of the Length of Job Spells

\begin{tabular}{llc}
\hline \hline & & $\begin{array}{c}\text { Average Job Length } \\
\text { (years) }\end{array}$ \\
\hline intemupted length of in-progress jobs & $\begin{array}{c}\mathbf{7 . 4}^{\mathrm{a}} \\
\text { complete length of in-progress jobs }\end{array}$ & $\mathbf{1 4 . 8}^{\mathrm{a}}$ \\
& $\begin{array}{l}\text { doubling approach } \\
\text { retention rate approach }\end{array}$ & $\mathbf{1 3 . 6}^{\mathrm{b}, \mathrm{c}}$ \\
complete length of a new job & & $\mathbf{2 . 0}^{\mathrm{a}}$ \\
\hline
\end{tabular}

Source: Hasan and de Broucker (1985)

a: 1980

b: 1981

c: Computed by the author from data supplied in Hasan and de Broucker (1985) table 6-7.

A second measure of job tenure we call the complete length of in-progress jobs. An early example of the estimation of this statistic is by Akerlof and Main (1981) who noted that in a steady state, the complete length of a job spell sampled in-progress is simply twice its intemupted length. Hasan and de Brouker reported this spell length to be $\mathbf{1 4 . 8}$ years for all individuals currently employed in 1980 . A more recent example of the computation of complete job lengths using this method is Christofides and McKenna (1993, 1995), who used longitudinal data from the 1986-87 and 198890 panels of the Canadian Labour Market Activity Survey (LMAS). The estimated complete length of jobs sampled in-progress fell between the two panels from 14.5 years to 14.0 years.

An altemate way of estimating the complete length of in-progress jobs was developed by Hall (1982) with extensions by Ureta (1992). These studies applied methods developed for the study of unemployment spell lengths to the study of job spells. The central concept of this methodology is the retention rate which is the conditional probability that a job will continue for some specified period of time, given that it has reached a certain tenure. Denoting the amount of tenure the worker has already experienced as $t$, the time as $c$ and the retention rate $\mathrm{R}_{t, c}$, the retention rate can be derived using two consecutive surveys as

$$
\mathrm{R}_{t, c}=\mathbf{N}_{t, c} \mathbf{N}_{t-1, c-l} \cdot
$$

This is simply the number of respondents reporting tenure of $t$ in the present survey divided by the number of respondents reporting tenure of $t-1$ in the previous survey. ${ }^{2} \mathrm{R}_{t, c}$ is one minus the hazard rate, and a full set of retention rates defines a survival function. The computation of the retention rate is an application of the synthetic cohort approach, so named because representative individuals from the same cohort, rather than the same specific individuals are sampled for the numerator and

2 Hall (1982), computed retention rates using a single cross section of data. Ureta (1992) demonstrates that retention rates calculated from a single survey are biased. To illustrate this consider a retention rate $R^{\prime}{ }_{t, c}$ computed from a single cross sectional survey:

$$
\mathrm{R}_{t, c}^{\prime}=\mathbf{N}_{t, c} \mathbf{N}_{t-1, c}
$$

Assuming a stable survivor function, $R^{\prime}{ }_{t, c}$ will be biased if $\mathbf{N}_{t-1, c} \neq \mathbf{N}_{t-1, c-1}$ which will occur if inflows to new jobs are changing. 
denominator. Using retention rates, Hall was able to add an estimate of remaining tenure to the distribution of intemupted spells available from Cument Population Survey (CPS) supplements, and thereby generate a distribution of complete job lengths. Hall's methodology was applied by Hasan and de Broucker (1985) using Canadian data from the Labour Force Survey (LFS) for 1981. This approach has the advantage over the simpler "doubling" method used by Akerlof and Main since it allows for the computation of the entire distribution of complete job spells but the average is similar at 13.6 years. These statistics rightly prompted the conclusion that the majority of time spent employed is in long-tem jobs.

Although useful, the distribution of in-progress spells, either in its intemupted or complete form, is inappropriate for examining changes in job tenure over time. To illustrate this point, consider the following formula for the average intemupted job length:

$$
\underset{\text { Job Length }}{\text { Average Interrupted }}=\frac{\sum_{t=1}^{n} \mathbf{N}_{1, c-t} \mathbf{S}_{t, c-t} \cdot \mathbf{t}}{\sum_{t=1}^{n} \mathbf{N}_{1, c-t} \mathbf{S}_{t, c-t}}
$$

$\mathbf{N}_{l, c-t}$ is the number of workers starting jobs in period c-t and $\mathbf{S}_{t, c-t}$ is the survival rate, or the probability that a job which begins at time c-t will last at least $t$ periods. The average intemupted job length in period $c$, is affected by the level of inflows in all previous periods in which someone currently with a job became employed, and all the respective survival rates in those periods. In a similar manner, the average complete job length of the currently employed is also affected by changes in past inflows and survival rates. This causes changes in either of these statistics over time to be difficult to interpret.

It is also important to note that the distribution of completed in-progress spells is an upwardly biased distribution of spell lengths. In a point-in-time survey, the probability of sampling a spell is proportionate to its length, making the distribution of in-progress jobs heavily weighted by long spells. As a result, Akerdof and Main (1981) refer to these measures as "experience weighted" since each job spell is weighted by its length. Akerlof and Main, Hall (1982), and Hasan and de Broucker (1985) argue that this is the appropriate distribution to study since it reflects the average experience of the employed. A discussion of how measuring spells in this way under-represents the importance of short spells in the context of measuring unemployment durations is provided by Carlson and Homigan (1893).

In this paper we focus on a third measure of job spells, which we call the complete length of a new job. Using a simple steady state approach and the restrictive assumption that retention rates are identical for all intemupted tenures, Hasan and de Broucker found that the average new spell in 1980 lasted just 2.0 years, illustrating the well known fact that while most time spent employed may be in long spells, the majority of employment spells are quite short. An altemate method to derive this statistic which we employ in this paper follows from Sider (1985), Baker (1992), and Corak and Heisz (1994) who applied it to the study of unemployment spells. This approach has the advantage that it does not rely on the restrictive steady state assumption. Again, the central concept to this methodology is the retention rate. Given a full set of retention rates, the expected average complete job length for a group of individuals who begin their jobs at the same time is defined to be: 


$$
\operatorname{AvgLength}_{c}=\sum_{t=1}^{n} \prod_{i=1}^{t} \mathrm{R}_{i, c}
$$

This equation is the discrete time version of the result that in continuous time the average duration of new job spells equals the integral of the survivor function. ${ }^{3}$ It measures the average length of time a group of workers who just begin their jobs will remain employed, assuming that they face the same economic conditions as cumently prevail for the remainder of their jobs. ${ }^{4}$ In a similar manner we can use retention rates to compute the distribution of complete job lengths for the newly employed. Let $\mathbf{E}_{t, c}$ be the proportion of jobs which end in the interval $(t-1, t)$ at time $c$. This can be estimated by subtracting the proportion of new jobs that survived longer than $t$ from the proportion of new jobs which survived longer than t-1. Since the proportion of new jobs which survive longer than $\mathbf{t}$ is $\prod_{i=1}^{t} \mathrm{R}_{i, c}$ then:

${ }^{3}$ See Baker and Trivedi (1985) for more details.

${ }^{4}$ The first element of equation (3) is one and $\mathbf{n}=420$. In practice sample size limitations dictate that tenure intervals longer than one month be used for retention rates. For the longest part of the distribution of intemupted job lengths there are sufficiently few responses to require interval widths of up to 5 years. Specifically, 16 retention rates are calculated over the period 1976 to 1994 . The retention rates are derived based upon the following ratios:

\begin{tabular}{|c|c|c|c|c|c|}
\hline $\mathrm{R}_{l, c}$ & $=\mathbf{3}-4$ & months tenure in month $\mathrm{c}$ & to & $1-2$ & months tenure in month $\mathrm{c}-2$ \\
\hline $\mathrm{R}_{2, c}$ & $=5-6$ & months tenure in month $\mathrm{c}$ & to & 3-4 & months tenure in month $\mathrm{c}-2$ \\
\hline $\mathrm{R}_{3, c}$ & $=7-8$ & months tenure in month $\mathrm{c}$ & to & $5-6$ & months tenure in month $\mathrm{c}-2$ \\
\hline $\mathrm{R}_{4, c}$ & $=13-18$ & months tenure in month $\mathrm{c}$ & to & $7-12$ & months tenure in month $\mathrm{c}-6$ \\
\hline $\mathrm{R}_{5, c}$ & $=25-36$ & months tenure in month $\mathrm{c}$ & to & 13-24 & months tenure in month c-12 \\
\hline $\mathrm{R}_{6, c}$ & $=37-48$ & months tenure in month $\mathrm{c}$ & to & $25-36$ & months tenure in month $\mathrm{c}-12$ \\
\hline $\mathrm{R}_{7, c}$ & $=49-60$ & months tenure in month $\mathrm{c}$ & to & $37-48$ & months tenure in month c-12 \\
\hline $\mathrm{R}_{8, c}$ & $=61-72$ & months tenure in month $\mathrm{c}$ & to & $49-60$ & months tenure in month c-12 \\
\hline $\mathrm{R}_{9, c}$ & $=\mathbf{8 5 - 1 0 8}$ & months tenure in month $\mathrm{c}$ & to & 61-84 & months tenure in month c-24 \\
\hline $\mathrm{R}_{10, c}$ & $=109-132$ & months tenure in month $\mathrm{c}$ & to & $85-108$ & months tenure in month c-24 \\
\hline $\mathrm{R}_{l l, c}$ & $=133-156$ & months tenure in month $\mathrm{c}$ & to & 109-132 & months tenure in month c-24 \\
\hline $\mathrm{R}_{12, \mathrm{c}}$ & $=157-180$ & months tenure in month $\mathrm{c}$ & to & 133-156 & months tenure in month $\mathrm{c}-24$ \\
\hline $\mathrm{R}_{13, c}$ & $=\mathbf{1 8 1 - 2 0 4}$ & months tenure in month $\mathrm{c}$ & to & 157-180 & months tenure in month c-24 \\
\hline $\mathbf{R}_{14, c}$ & $=241-300$ & months tenure in month $\mathrm{c}$ & to & $181-240$ & months tenure in month $\mathrm{c}-60$ \\
\hline $\mathrm{R}_{15, \mathrm{c}}$ & $=\mathbf{3 0 1 - 3 6 0}$ & months tenure in month $\mathrm{c}$ & to & 241-300 & months tenure in month $\mathrm{c}-60$ \\
\hline & $=361-420$ & months tenure in month $\mathrm{c}$ & to & 301-360 & months tenure in month c-60 \\
\hline
\end{tabular}

For the purpose of computing average tenure of new jobs, these retention rates are converted to monthly equivalents by raising them to the inverse of their respective interval width. This assumes that monthly retention rates are constant within the interval.

These retention rates can in tum be converted to broader widths by multiplying them together. For example, the probability of a job lasting to beyond 6 months at time c given as $R_{1, c} * R_{2, c} * R_{3, c}$. Similarty the conditional probability of a job lasting to beyond 5 years given that it lasts to 6 months is $\mathrm{R}_{4, \mathrm{c}}{ }^{*} \mathrm{R}_{5, \mathrm{c}}{ }^{*} \mathrm{R}_{6, \mathrm{c}} * \mathrm{R}_{7, \mathrm{c}} * \mathrm{R}_{8, \mathrm{c}}$.

Because few respondents report more than 360 months of tenure, retention rates beyond 360 months are not computed. This is done for methodological convenience, but since this represents a small tail of the tenure distribution this is not expected to affect results. Corak and Heisz (1994) have shown that it is important when using this method to have narrow intervals for the densest part of the distribution, which in this case is at the shorter tenures. 


$$
\mathbf{E}_{t, c}=\prod_{i=1}^{t-1} \mathrm{R}_{i, c}-\prod_{i=1}^{t} \mathrm{R}_{i, c}
$$

This requires the same assumptions to be made as for the average eventual tenure statistic. $\mathbf{E}_{t, c}$ represents the proportion of jobs which end in the interval $(t-1, t)$ given that the present economic conditions remain unchanged through the life of the spells.

The complete length of a new job statistic is useful for measuring the length of job spells because it is not biased in favour of longer jobs. Also, in contrast to job length estimates derived directly from the distribution of in-progress spells, the complete length of new job spell, as defined in equation (3) and (4), relies upon retention rates generated from the current and most recent periods and is not inherent to problems in interpretation caused by changes in past inflows and survival functions. ${ }^{5}$ As a result it is also more appropriate than altemate measures of job lengths for investigating changes in job tenure over time. ${ }^{6}$ Except when explicitly stated, the remainder of the paper will deal with the complete length of new jobs.

Most recent studies have sidestepped the issue of estimating average job lengths and followed one of two approaches. Farber (1995) and Green and Riddell (1995) look at changes in the distribution of intemupted job tenures in the U.S. and Canada respectively, even though, as noted above, changes in this distribution are hard to interpret. Examining Canadian data from 1979 to 1991, Green and Riddell observe a tendency towards shorter job spells particularly for the younger and less educated, as well as declines in the proportions of in-progress jobs lasting 6 to 10 years and increases in the proportion of workers in 11 to 20 year old jobs. Diebold, Neumark and Polsky (1994) and Swinnerton and Wial (1995) focus directly upon changes in retention rates, but each research group, using similar data from the U.S. Current Population Survey (CPS) reaches a different conclusion. Diebold et al., find that four year retention rates are quite stable while Swinnerton and $W$ ial find a significant drop in 4 year rates over the 1980s. A subsequent communication by Diebold, Neumark and Polsky (1996) found the latter results to be in emor because of sample selection problems and small differences in methodology. Deibold et al., found that four year retention rates overall were 0.52 in 1983 and 0.51 in 1987 implying no overall decline in job stability. This conclusion is maintained when workers are stratified by current tenure. As we show later, most job spells last less than 4 years so this statistic may be missing potentially important changes in job stability.

\footnotetext{
5 As noted in endnote four, we use intervals longer than one month, so our estimate will be influenced by changes in past retention rates and inflows. However, the estimate for new job lengths is less susceptible to these biases than that of current job length. There are two reasons for this. First, most retention rates defined in endnote 4 require two or fewer years lag. Second, the effects of longer lags for retention rates at $\mathbf{1 5}$ years of tenure and longer are mitigated by the fact that very few new jobs reach tenures of this length. Nevertheless, the effects of wider intervals at long tenures should be sufficient to cause changes in this statistic to lag changes in the economy.

${ }^{6}$ Application of (3) is not limited to predicting the job lengths of the newly employed. Since the statistic is composed of information from job holders drawn from the entire cohort of currently employed, changes in job stability for jobs of any length will be reflected in this statistic, as weighted by the probability that a new job will reach that length.
} 
In this study we compute the average complete length of a new job and the distribution of new job lengths for the period 1981 through 1994. The tenure $t$ is obtained from the Canadian Labour Force Survey as the number of consecutive months of intemupted work for the current employer. ${ }^{7}$ This is available monthly for a representative sample of about 60,000 Canadians from 1976 to the present. The sample used for this study includes all full and part time paid workers, excluding the self employed, full time students ${ }^{8}$ and unpaid family workers. Although most comparable work in this subject has used U.S. data, Canadian data is better suited to the study of tenure for at least three reasons. First, Canadian tenure data is available monthly, compared to that in the U.S. which is available only in intervals of at least two years. This allows the computation of retention rates at narrower intervals than is possible with U.S. data and permits us to evaluate changes in job stability for shorter jobs. Second, the questions asked of Canadians has been consistent throughout the time frame while in the U.S. the data series is broken by a change in the question between the 1981 and 1983 tenure supplements. ${ }^{9}$ Third, in Canada the tenure questions are asked as part of the regular LFS, while in the U.S. they are asked in a supplement to the CPS, resulting in substantial nonresponse which does not occur in Canada.

\section{Changes in Job Stability}

Figure 1 illustrates the average length of a new job from 1981 to 1994 for all workers in our sample. Over this period new jobs lasted an average of 3.7 years. ${ }^{10}$ Although the average length of jobs followed a cyclical pattem, varying from lows of 3.5 years in 1982 and 3.0 years in 1991 to peaks of 4.0 years in 1985 and 4.9 years in 1994, it showed no significant trend. The average new job lasted 3.8 years between 1981 and 1985, 3.4 years between 1986 and 1990, and 3.8 years between 1991 and 1994.

Masked by the stability in the average lengths of jobs are important changes in the distribution of completed job lengths. This distribution is shown in figure 2 , averaged at the beginning and the end of the period. There has been a substantial shift from jobs which last between 6 months and 5 years to those which last 6 months or less. Between the periods 1981-85 and 1991-94 the proportion of jobs which lasted between 6 months and 5 years dropped from 34 to 26 percent while the

7 For multiple job holders, tenure is measured for the primary job. An absence of work due to vacation, illness, temporary layoff or other reason is not considered a break in employment unless the person leaves the job in the course of the absence. See Statistics Canada (1992).

8 Students include those full time in the month of the survey, and, for the months of May to September, returning students. Returning students were full time in March of the current calendar year and intended to return to school in the fall.

9 The question in Canada is more similar to the initial question asked in the U.S.. In Canada, LFS respondents are asked: "When did ... start working for the current employer". This is shown by Diebold et al., (1994) to supply less response bias than an altemate question, asked of U.S. respondents after 1983: "How long has ... been working for his present employer (or as self employed)".

${ }^{10}$ The average length of new jobs is much shorter than either the intemupted or complete measures of jobs sampled in-progress. The average intermupted job length over the period 1981-1994 was 7.5 years while the average complete job length was estimated to be $\mathbf{1 7 . 4}$ years. This illustrates the well known fact that while new jobs tend to be short, most time spent employed is in long jobs. 
proportion of jobs lasting 6 months or less increased from 46 to 54 percent. The proportion of jobs estimated to last between 5 and 20 years and more than 20 years remained unchanged over the period. Fully 14 percent of jobs will last between 5 and 20 years and 6 percent will last longer than 20 years. This increase in the proportion of short-term jobs combined with an unchanging proportion long-term jobs represents a polarization of jobs.

How is it that the proportion of long-term jobs has remained stable even though the proportion of short-term jobs has increased? The answer is that once a job has passed the 6 month milestone it had a better chance of becoming a long job at the end of the period than it did at the beginning. This is shown in figure 3. The upper line shows the proportion of new jobs which go on to last beyond 6 months while the lower line shows the proportion of 6 month old jobs which go on to last more than 5 years. While the proportion of new jobs which lasted beyond 6 months declined over the period, the proportion of 6 month old jobs which lasted longer than 5 years increased from an average of 37 percent between 1981 and 1985 to an average of 42 percent between 1991 and 1994. These changes mean workers with more than one year of job seniority are enjoying increasing stability while at the same time the ranks of stable job holders is becoming more difficult to join.

\section{Polarization of Jobs, A Closer Look}

Polarization of complete job lengths could occur if some demographic groups were enjoying longer jobs while others were not. Altemately, polarization could occur within all groups. The first result would suggest that it is some sectoral or demographic factor, such as the region or industry of employment, the age or gender of the worker, or the educational attainment of the worker which is increasing in importance for attaining a long-term job. The second result implies that the changes are economy wide and affect all workers. This section of the paper addresses this question by investigating if the pattems which appear in the aggregate also appear within specific sectors or groups in the economy.

Summary statistics according to several breakdowns are given in Table 2. Statistics include the average length of a new job, the proportion of new jobs which exceed 6 months in length, the proportion of 6 month old jobs which exceed 5 years in length and the proportion of five year old jobs which exceed twenty years in length. The results are given by gender of worker, age when the worker started his or her job, region of employment, industry of employment, and educational attainment of the worker. Only the four largest industries are profiled. These are community sevvices, manufacturing, trade, and business and personal services. A change in the definition of educational attainment in 1990 prevents calculation of average job lengths and the proportion of 5 year old jobs which exceed 20 years in length after 1989. For the proportion of new jobs which exceed 6 months in length and the proportion of 6 month old jobs which exceed 5 years in length, averages exclude observations from 1990. 
Figure 1: Average Complete Job Length, 1981 to 1994

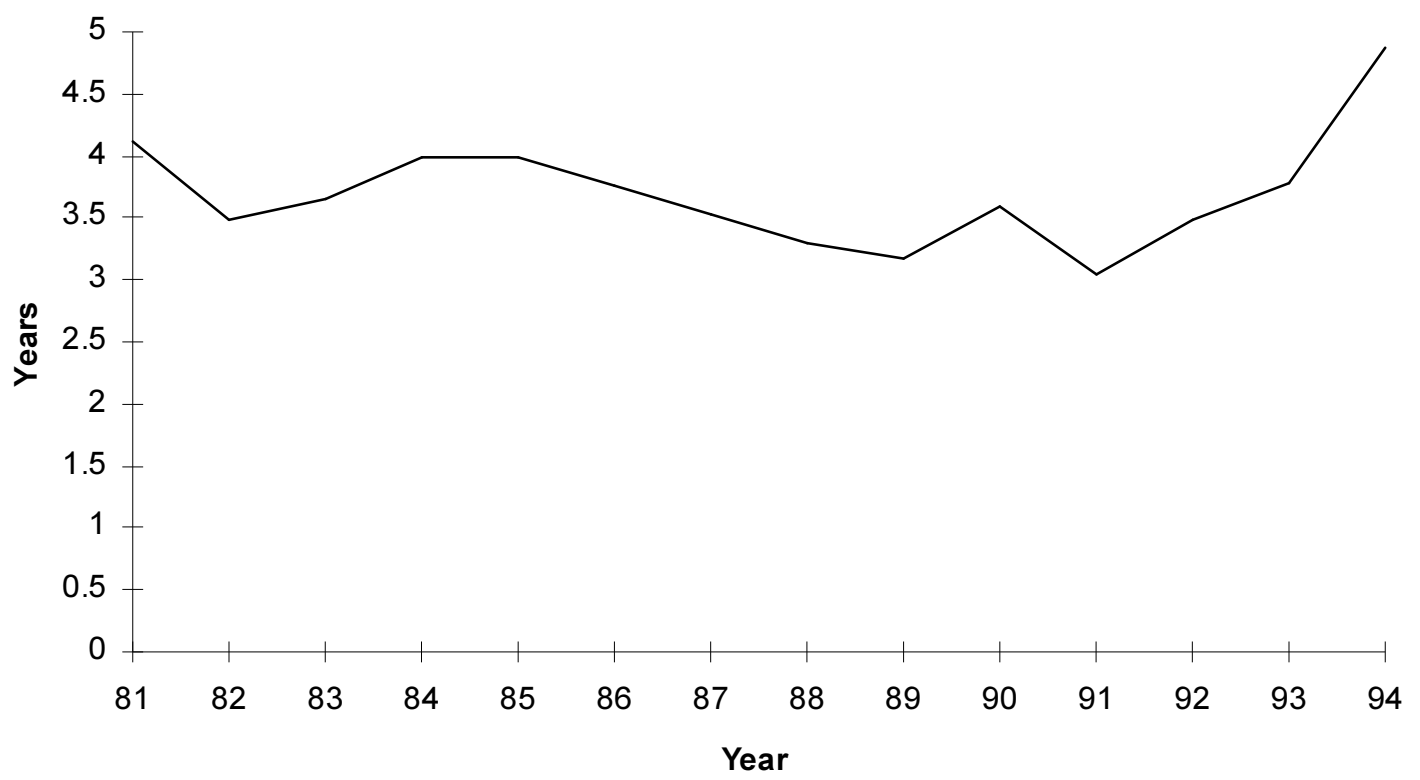

Figure 2: Distribution of Complete Job Lengths, 1981-85 and 1991-94

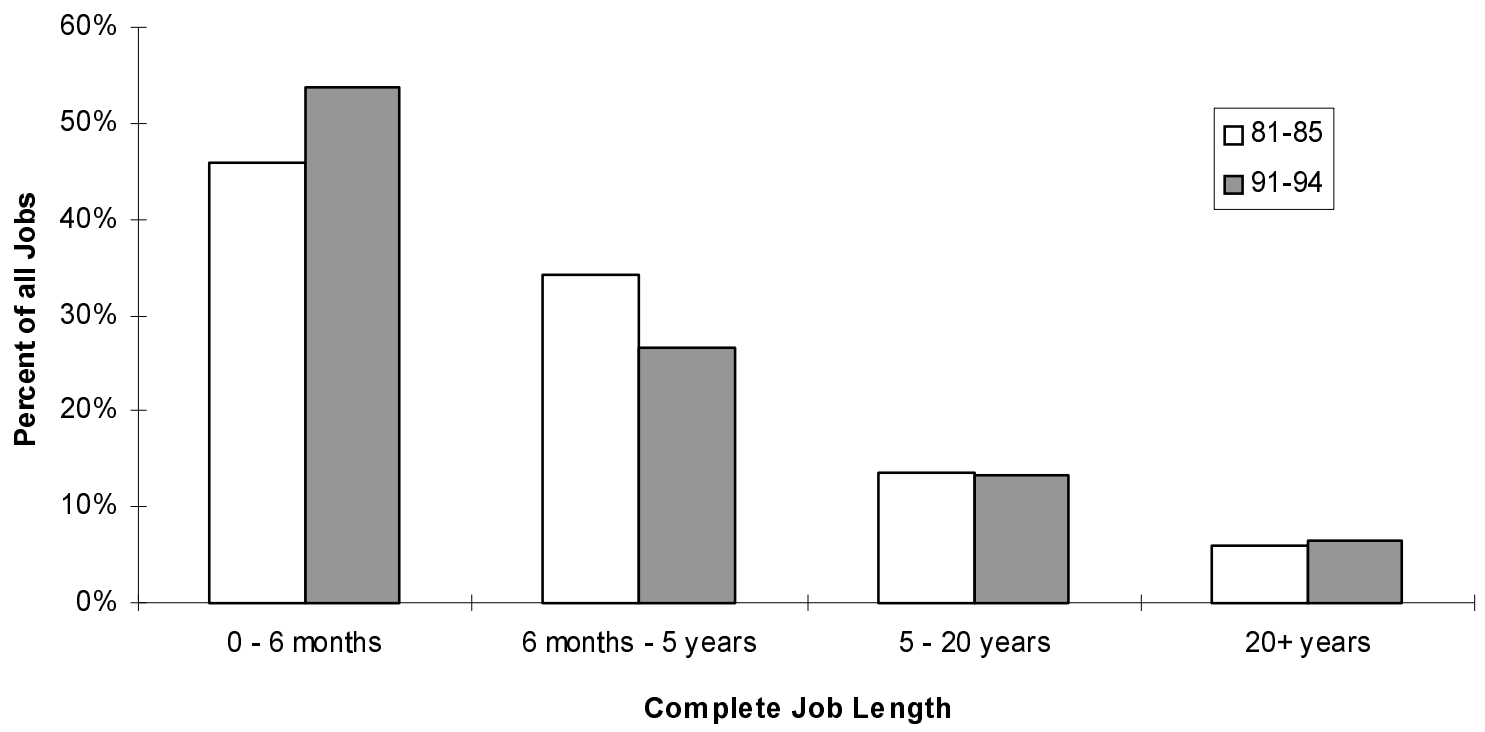


Figure 3: Changes in The Distribution of Complete Job Lengths, 1981-1994

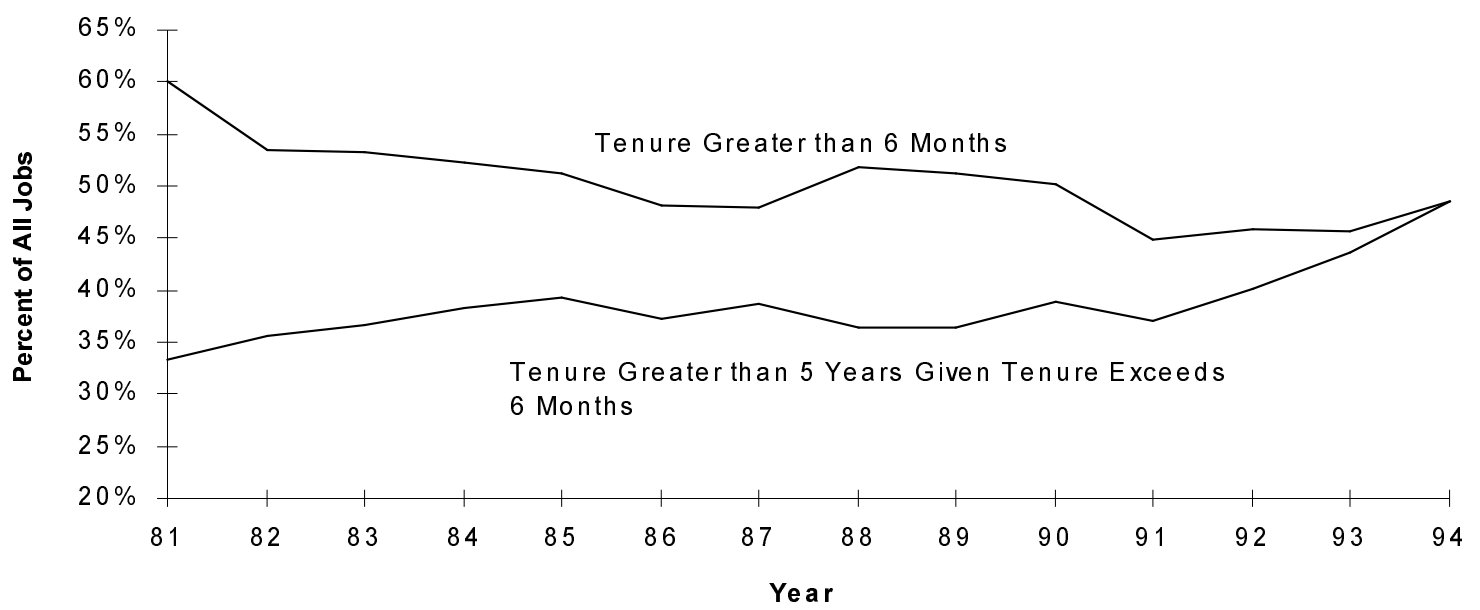

Table 2

Average Complete Job Length, Selected Portions of the Distribution of Completed Jobs, by Demographic Group, 1981-1994

\begin{tabular}{|c|c|c|c|c|}
\hline & \multirow{2}{*}{$\begin{array}{l}\text { Average Complete } \\
\text { Job Length (Years) }\end{array}$} & \multicolumn{3}{|c|}{ The Proportion Of New Jobs $W$ hich Last Longer Than ... } \\
\hline & & 6 Months & $\begin{array}{c}5 \text { Years Given They } \\
\text { Lasted Longer Than } 6 \\
\text { Months } \\
\end{array}$ & $\begin{array}{c}20 \text { Years Given They } \\
\text { Lasted Longer Than } 5 \\
\text { Years }\end{array}$ \\
\hline All & 3.7 & 50.4 & 38.6 & 30.4 \\
\hline Males & 3.6 & 48.0 & 39.0 & 31.7 \\
\hline Females & 3.8 & 53.2 & 38.3 & 27.9 \\
\hline \multicolumn{5}{|l|}{ Age $W$ hen Job Began } \\
\hline $15-24$ years & 3.7 & 45.9 & 37.3 & 39.0 \\
\hline 25-34 years & 4.3 & 55.7 & 37.3 & 38.5 \\
\hline $35-44$ years & 4.0 & 53.8 & 44.2 & 23.9 \\
\hline 45-54 years & 3.2 & 49.1 & 43.7 & 4.1 \\
\hline 55-64 years & 1.9 & 41.8 & 31.7 & 1.3 \\
\hline \multicolumn{5}{|l|}{ Region of Employment } \\
\hline Atlantic Canada & 2.6 & 34.6 & 36.9 & 31.5 \\
\hline Quebec & 3.6 & 46.8 & 40.8 & 31.1 \\
\hline Ontario & 4.5 & 58.6 & 40.7 & 30.6 \\
\hline Westem Canada & 3.4 & 50.2 & 35.2 & 29.3 \\
\hline \multicolumn{5}{|l|}{$\begin{array}{l}\text { Industry of } \\
\text { Emplovment }\end{array}$} \\
\hline Community Sevvices & 5.4 & 54.1 & 49.6 & 40.3 \\
\hline Manufacturing & 4.0 & 51.4 & 41.4 & 27.9 \\
\hline Trade & 3.8 & 61.2 & 34.6 & 20.9 \\
\hline $\begin{array}{l}\text { Business and Personal } \\
\text { Services }\end{array}$ & 2.7 & 51.6 & 27.2 & 19.6 \\
\hline \multicolumn{5}{|l|}{ Educational Attainment } \\
\hline No Post Secondary & $2.9^{\mathrm{a}}$ & $42.2^{\mathrm{b}}$ & $33.1^{\mathrm{b}}$ & $24.4^{\mathrm{a}}$ \\
\hline Some Post Secondary & $5.7^{\mathrm{a}}$ & $60.7^{b}$ & $43.2^{\mathrm{b}}$ & $42.1^{\mathrm{a}}$ \\
\hline
\end{tabular}

a) 1981-89 only. A change in the LFS definition of educational attainment in 1990 prevents calculation of these statistics past 1989.

b) 1981-1989, 1991-1994 only. Observations from 1990 omitted due to a change in the LFS definition of educational attainment in that year. 
There is clearly a premium associated with belonging to certain demographic groups. For example, average tenure is 1.7 times longer in Ontario than the Atlantic Provinces. Workers in the community services industry enjoy average job lengths which are twice that of those in the business and personal services industry, and workers with some post secondary education have average job lengths almost twice the length of those without. Older workers have shorter average job lengths than younger workers, and fewer older job starters pass the 6 month tenure milestone (we discuss older workers in more depth below). Also notable is that females have jobs which are on average slightly longer than males. This is mainly due to a higher probability that a new job will exceed 6 months in length for females. ${ }^{11}$

The pattem of change over the period in the distribution of complete job lengths is qualitatively similar for each sub-group studied as it is in the aggregate. This is confirmed by the results of regressions of 168 monthly values of each of the variables in Table 2 upon monthly dummies, the unemployment rate, and a linear time trend. Results for the time trend are shown in Table 3. For reporting convenience the trend variable numbers from 0.001 to 0.168 so coefficient estimates represent the average monthly change in the dependent variable $\times 1000$ over the period. ${ }^{12}$ There is a significant amount of autocomelation in each series so the results are comected for $A R(1)$.

The probability that a new job would last longer than 6 months declined significantly for all groups. Hardest hit were females, workers over age 55, workers in Atlantic Canada, workers in the community services industry and workers with some post secondary education. These declines are substantial in magnitude. For example, coefficient estimates for females suggest that the probability a new job will last beyond 6 months fell by 1.8 percent per year, or 25 percent over the whole period. Thus, 25 percent fewer female job starters held those jobs beyond 6 months at the end of the period than the beginning. This amounts to a drop in this probability of 13.5 percentage points (evaluated at the period mean). The comesponding drop for males is 7.4 percentage points.

${ }^{11}$ This finding runs contrary to the common perception that females have shorter job tenure on average than males. This usually comes from an examination of interrupted or complete in-progress spell lengths which, as shown above, are susceptible to changes in participation rates. Over the period 1966 to 1994 the female labour force participation rate rose by 22 percent while that of men declined by 6 percent. This change has the effect that the stock of employed females during the 1981-94 period is more heavily weighted with individuals who have been in the labour force a shorter amount of time, and will have lower interrupted tenure than the stock of employed males over the period. Our estimates for the average complete length of in-progress spells by gender are 18.3 years for males and 16.3 years for females. In addition, past estimates for the length of current job spells were often based upon contemporaneous rather than historical retention rates. As noted in endnote 2, complete job lengths are affected by changes in inflows to employment when contemporaneous retention rates are used. Hasan and de Broucker (1985) estimated that the median complete length of an in-progress spell in 1981 to be 12.4 years for men and 6.1 years for women using contemporaneous rates. Our estimates for 1981, using a slightly different sample and historical retention rates imply that the median complete length of an in-progress spell to be 12.1 years for men and 10.4 years for women.

${ }^{12}$ The specific model used is:

$\log \mathrm{D} V=\mathbf{a}+\mathbf{b M O N T H L Y}{ }_{-}$DUMMIES + cTIME + d logUNEMPLOYMENTRATE

$\mathrm{D} V$ is the dependent variable identified at the top of each column of table 2. Changes in average job length and in the proportion of 5 year old jobs which last beyond 20 years are available by educational attainment only to 1989 and are not shown. Changes in the proportion of new jobs which last beyond 6 months and the proportion of 6 month old jobs that last beyond 5 years by educational attainment, are based upon 156 monthly observations for 1981-1989 and 1991-1994. Complete regression results are available upon request. 
Table 3

Changes in Average Job Length and the Distribution of Completed Jobs by Demographic Group, 1981-1994

\begin{tabular}{|c|c|c|c|c|}
\hline & \multirow{3}{*}{$\begin{array}{c}\text { Average } \\
\text { Complete Job } \\
\text { Length (Years) } \\
\\
\\
\\
\mathbf{0 . 0 5 5} \\
(\mathbf{0 . 7 9 5 )}\end{array}$} & \multicolumn{3}{|c|}{ The Proportion Of New Jobs $W$ hich Last Longer Than ... } \\
\hline & & \multirow{2}{*}{$\begin{array}{c}6 \text { Months } \\
\\
\begin{array}{c}-1.186 \\
(0.195)^{* * * *}\end{array}\end{array}$} & \multirow{2}{*}{$\begin{array}{c}5 \text { Years Given They } \\
\text { Lasted Longer Than } \\
6 \text { Months } \\
1.343 \\
(0.495)^{* * *}\end{array}$} & $\begin{array}{l}20 \text { Years Given They } \\
\text { Lasted Longer Than } 5 \\
\text { Years }\end{array}$ \\
\hline All & & & & $\begin{array}{c}\mathbf{0 . 8 3 3} \\
(1.427)\end{array}$ \\
\hline Males & $\begin{array}{c}0.094 \\
(0.722)\end{array}$ & $\begin{array}{c}-0.920 \\
(0.237)^{* * *}\end{array}$ & $\begin{array}{c}1.121 \\
(0.622)^{*}\end{array}$ & $\begin{array}{c}0.554 \\
(\mathbf{1 . 0 6 5})\end{array}$ \\
\hline Females & $\begin{array}{c}\mathbf{- 0 . 0 9 4} \\
(\mathbf{0 . 7 4 2})\end{array}$ & $\begin{array}{c}-1.512 \\
(0.212)^{* * * *}\end{array}$ & $\begin{array}{c}1.573 \\
(0.617)^{* *}\end{array}$ & $\begin{array}{c}1.300 \\
(1.957)\end{array}$ \\
\hline \multicolumn{5}{|c|}{ Age $W$ hen Job Began } \\
\hline $15-24$ years & $\begin{array}{c}0.586 \\
(0.977)\end{array}$ & $\begin{array}{c}-0.999 \\
(0.278)^{* * *}\end{array}$ & $\begin{array}{c}1.902 \\
(0.717)^{* * * *}\end{array}$ & $\begin{array}{c}1.166 \\
(2.330)\end{array}$ \\
\hline 25-34 years & $\begin{array}{c}-0.312 \\
(0.790)\end{array}$ & $\begin{array}{c}-1.249 \\
(0.257)^{* * * *}\end{array}$ & $\begin{array}{c}1.189 \\
(0.544)^{* *}\end{array}$ & $\begin{array}{c}-\mathbf{0 . 1 3 3} \\
(\mathbf{1 . 4 4 4 )}\end{array}$ \\
\hline 35-44 years & $\begin{array}{l}-\mathbf{0 . 4 4 9} \\
(\mathbf{0 . 4 9 0})\end{array}$ & $\begin{array}{c}-1.367 \\
(0.283)^{* * *}\end{array}$ & $\begin{array}{c}1.101 \\
(0.527)^{* *}\end{array}$ & $\begin{array}{c}-1.232 \\
(1.068)\end{array}$ \\
\hline $45-54$ years & $\begin{array}{c}-1.601 \\
(0.815)^{* *}\end{array}$ & $\begin{array}{c}-1.572 \\
(0.443)^{* * * *}\end{array}$ & $\begin{array}{l}-0.325 \\
(1.153)\end{array}$ & $\begin{array}{c}1.224 \\
(2.104)\end{array}$ \\
\hline 55-64 years & $\begin{array}{c}-2.920 \\
(0.974)^{* * *}\end{array}$ & $\begin{array}{c}-4.063 \\
(\mathbf{0 . 5 0 8})^{* * *}\end{array}$ & $\begin{array}{c}2.014 \\
(1.891)\end{array}$ & $\begin{array}{c}-2.728 \\
(4.735)\end{array}$ \\
\hline \multicolumn{5}{|c|}{$\begin{aligned} * * * & \text { significant at the } 1 \% \text { level } \\
* * * & \text { significant at the } 5 \% \text { level } \\
* & \text { significant at the } 10 \% \text { level }\end{aligned}$} \\
\hline \multicolumn{5}{|c|}{$\begin{array}{l}\text { a) Trend coefficients from regression of dependant variables (168 monthly observations) upon monthly dummy variables, log } \\
\text { unemployment rate and a linear time trend. Coefficients represent average monthly change * } 1000 \text { over the period. All results } \\
\text { are comected for } A R(1) \text {. }\end{array}$} \\
\hline & & & & Continue... \\
\hline
\end{tabular}

Table 3

Changes in Average Job Length and the Distribution of Completed Jobs by Demographic Group, 1981-1994ª (continued) 


\begin{tabular}{|c|c|c|c|c|}
\hline & \multirow{2}{*}{$\begin{array}{l}\text { Average Complete } \\
\text { Job Length (Years) }\end{array}$} & \multicolumn{3}{|c|}{ The Proportion Of New Jobs $W$ hich Last Longer Than ... } \\
\hline & & 6 Months & $\begin{array}{l}5 \text { Years Given They } \\
\text { Lasted Longer Than } \\
6 \text { Months }\end{array}$ & $\begin{array}{l}20 \text { Years Given They } \\
\text { Lasted Longer Than } 5 \\
\text { Years }\end{array}$ \\
\hline \multicolumn{5}{|l|}{ Region of Employment } \\
\hline Atlantic Canada & $\begin{array}{c}-1.543 \\
(0.801)^{*}\end{array}$ & $\begin{array}{c}-2.403 \\
(0.337)^{* * * *}\end{array}$ & $\begin{array}{c}\mathbf{0 . 6 7 7} \\
(\mathbf{0 . 8 8 9})\end{array}$ & $\begin{array}{c}\mathbf{0 . 7 2 4} \\
(\mathbf{0 . 9 5 7})\end{array}$ \\
\hline Quebec & $\begin{array}{l}-\mathbf{0 . 0 7 1} \\
(\mathbf{0 . 8 9 4})\end{array}$ & $\begin{array}{c}-1.259 \\
(0.292)^{* * * *}\end{array}$ & $\begin{array}{c}1.149 \\
(0.952)\end{array}$ & $\begin{array}{c}0.700 \\
(1.590)\end{array}$ \\
\hline Ontario & $\begin{array}{c}0.266 \\
(0.723)\end{array}$ & $\begin{array}{c}-0.749 \\
(0.227)^{* * * *}\end{array}$ & $\begin{array}{c}1.116 \\
(0.575) *\end{array}$ & $\begin{array}{c}0.563 \\
(1.687)\end{array}$ \\
\hline Westem Canada & $\begin{array}{c}0.340 \\
(0.511)\end{array}$ & $\begin{array}{c}-1.121 \\
(0.293)^{* * * *}\end{array}$ & $\begin{array}{c}1.903 \\
(0.335)^{* * *}\end{array}$ & $\begin{array}{c}0.752 \\
(1.168)\end{array}$ \\
\hline \multicolumn{5}{|l|}{ Industry of Employment } \\
\hline Community Senvices & $\begin{array}{l}-0.727 \\
(0.868)\end{array}$ & $\begin{array}{c}-2.315 \\
(0.319)^{* * * *}\end{array}$ & $\begin{array}{c}1.588 \\
(0.458)^{* * *}\end{array}$ & $\begin{array}{c}1.185 \\
(2.051)\end{array}$ \\
\hline Manufacturing & $\begin{array}{c}0.186 \\
(1.467)\end{array}$ & $\begin{array}{c}-1.336 \\
(0.486)^{* * * *}\end{array}$ & $\begin{array}{c}2.457 \\
(1.253)^{* *}\end{array}$ & $\begin{array}{l}-0.609 \\
(1.645)\end{array}$ \\
\hline Trade & $\begin{array}{l}-0.526 \\
(0.476)\end{array}$ & $\begin{array}{c}-0.791 \\
(0.228)^{\div \div *}\end{array}$ & $\begin{array}{c}0.841 \\
(0.509)^{*}\end{array}$ & $\begin{array}{c}-1.958 \\
(1.013)^{*}\end{array}$ \\
\hline $\begin{array}{l}\text { Business and } \\
\text { Personal Services }\end{array}$ & $\begin{array}{c}1.547 \\
(0.920)^{*}\end{array}$ & $\begin{array}{c}-0.673 \\
(0.285)^{* * *}\end{array}$ & $\begin{array}{c}1.548 \\
(1.462)\end{array}$ & $\begin{array}{c}3.336 \\
(1.402)^{* *}\end{array}$ \\
\hline \multicolumn{5}{|l|}{ Educational Attainment } \\
\hline No Post Secondary & b & $\begin{array}{c}-2.207^{\mathrm{c}} \\
(0.247)^{\dot{*} * *}\end{array}$ & $\begin{array}{c}0.397^{\mathrm{c}} \\
(\mathbf{0 . 6 3 8})\end{array}$ & $\mathrm{b}$ \\
\hline Some Post Secondary & $\mathrm{b}$ & $\begin{array}{c}-2.765^{\mathrm{c}} \\
(0.347)^{* * * *}\end{array}$ & $\begin{array}{c}0.286^{c} \\
(1.130)\end{array}$ & $\mathrm{b}$ \\
\hline \multicolumn{5}{|c|}{$\begin{array}{l}* * \text { significant at the } 1 \% \text { level } \\
* * \text { significant at the } 5 \% \text { level } \\
* \text { significant at the } 10 \% \text { level }\end{array}$} \\
\hline \multicolumn{5}{|c|}{$\begin{array}{l}\text { b) A change in the LFS definition of educational attainment in } 1990 \text { prevents calculation of these statistics. } \\
\text { c) Results from } 156 \text { observations. Observations from } 1990 \text { omitted due to a change in the LFS definition of educational } \\
\text { attainment in that year. }\end{array}$} \\
\hline
\end{tabular}


At the same time, the proportion of 6 month old jobs which lasted longer than 5 years increased significantly for most groups. This proportion increased most for females, workers between the ages of 25 and 44 when their jobs began, workers in Westem Canada, and workers in the manufacturing and community services industries. Again the sizes of these changes are significant. For females who reach 6 months of tenure, 10.2 percentage points more hold these jobs beyond 5 years in the mid 1990's than was the case in the early 1980's. For males this increase amounts to 7.3 percentage points. This proportion increased, but not significantly for workers in Atlantic Canada and Quebec, workers in the business and personal services industry and those aged 55-64 when they began their jobs.

The proportion of 5 year old jobs which would continue to last more than 20 years remained stable for most groups. All coefficients were insignificant with the exception of those for the trade and the business and personal services industries. In the trade industry, the proportion of 5 year old jobs which would go on to last more than 20 years declined by 6.9 percentage points while in the business and personal services industry it increased by 11.0 percentage points.

Despite these changes in the distribution of complete jobs, average job lengths for most groups remained steady, with some notable exceptions. First, workers aged 45-54 and 55-64 when they started their jobs experienced significantly shorter jobs at the end of the period compared to the beginning. The coefficient estimates imply that for each of these groups the average complete length of a new job fell by 0.9 years between 1981 and 1994. Second, workers in the Atlantic provinces experienced a decline in the average length of a job of 0.7 years. Third, workers in the business and personal services industry enjoyed longer jobs at the end of the period than at the beginning. For these workers average tenure increased by 0.7 years over the period.

Both the relatively lower average job length, and the relatively large decline in average job length among older workers raise the concem that older displaced workers are left with skills not in demand and few employment prospects. Three altemate explanations are that older workers are increasingly (1) retiring earlier, (2) supplementing retirement income with short-term work, or (3) bridging the time between the end of a more permanent job to retirement with one or more shortterm jobs. Data in Table 3 shows that the proportion of job starters that achieve stable employment is declining at a much faster rate for workers aged 55-64 than it is for younger workers. Regression results imply that the proportion of jobs started by workers aged 55-64 which lasted more than 6 months declined by 4.9 percent per year, while for all other groups this proportion declined by no more than 1.9 percent per year. Furthermore, the trend observed for all workers that 6 month old jobs are increasingly likely to last beyond 5 years is reserved to younger workers. The probability that a job started by a worker aged 45-54 would last to beyond 5 years given it lasted 6 months actually declined, although not significantly. Similarty, for workers aged 55-64 when their jobs began this probability rose but not significantly. These trends combine to produce the result that older job starters are having an increasingly difficult time achieving job stability.

Similar trends underlie the decline in job lengths in Atlantic Canada. Declines in the average length of a new job are caused by exceptionally large declines in the proportion of jobs which last longer than 6 months coupled with little or no increase in the probability that 6 month old jobs will last longer than 5 years. Thus, while for most groups we looked at changes in the distribution of job lengths is characterized by polarization, for older job starters and those from Atlantic Canada, these changes are better described as a shift towards more short-term jobs. 


\section{Older Workers and Long Lasting Jobs}

There is an often heard argument that because of structural changes in the economy older workers are at an increased risk of losing what were once stable jobs. One way of examining this question is to look at changes in five year retention rates for workers of various ages and intemupted job lengths. Table 4 contains the time trend estimates from regressions of selected five year retention rates upon monthly dummies, the log of the unemployment rate and a linear time trend for workers of various ages. Each coefficient gives the monthly change in the probability that, for example, a job held by a worker aged between 35 and 44 that has lasted between 10 and 14 years will continue on for another 5 years. As in Table 3, the monthly change has been multiplied by 1000 and the results are corrected for $A R(1)$.

There is strong evidence, particularly for older workers with high senionity, that 5 year retention rates declined through the period. Again, these declines were significant in magnitude. For workers currently aged 50-59 with 15-19 years of tenure, the probability that that job would last another 5 years declined by 1.8 percent per year, or 26 percent over the 14 year period. For younger workers and workers with less seniority there was no significant change. Unfortunately it is not possible to tell with this data what is driving this change. Although some of it will be due to increasing job loss, some will also be the result of the rising prevalence of early retirement for older workers. That declines in retention rates were concentrated among older workers with high senionity suggests that the second explanation is more important.

Structural changes in the economy are also identified as having caused increased instability in long jobs held in certain industries. Changes in 5 year retention rates for jobs of various intemupted lengths in the manufacturing, trade, community services and business and personal services are shown in Table 5. ${ }^{13}$ Long jobs held in the manufacturing and trade industries are less stable now than in the early 1980s, but this change is not large and is offset by an increased stability of long jobs in the community services and business and personal services industries. This rate declined significantly only for jobs in the manufacturing industry which had lasted between 20 and 24 years which may be partially due to an increased prevalence for early retirement. This change amounted to a 12.8 percent decline in the proportion of these jobs which continued for 5 more years. Changes in retention rates for long jobs in the trade industry, although jointly significant in Table 3, are individually not significant in Table 5, although they are consistently negative. Five year retention rates for 15-19 year old jobs in the community senvices industry and 10-14 year old jobs in the business and personal services industry increased by 8.5 and 27.9 percent respectively.

${ }^{13}$ Derived from regression of five year retention rates upon monthly dummies, the log of the unemployment rate and a linear time trend. Results are corrected for $\mathrm{AR}(1)$ and represent the monthly change in retention rates $\times 1000$. 
Table 4

Changes in the Retention Rates of Long Lasting Jobs by Current Age of Worker, 1981-1994ª

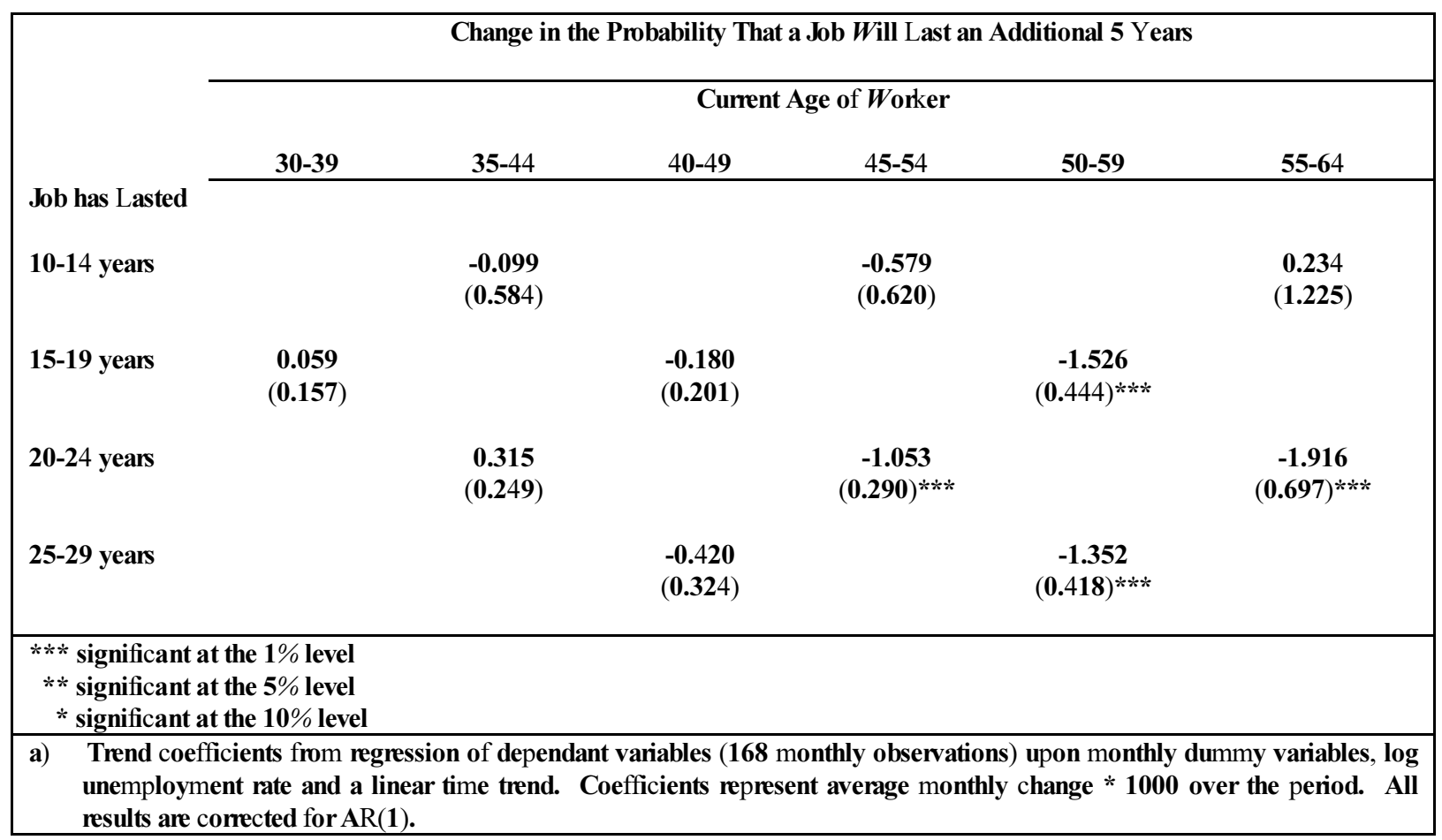

Table 5

Changes in the Retention Rates of Long Lasting Jobs, by Industry, 1981-1994ª

\begin{tabular}{|c|c|c|c|c|}
\hline & \multicolumn{4}{|c|}{ Change in the Probability That a Job $W$ ill Last an Additional 5 Years } \\
\hline & $\begin{array}{l}\text { Community } \\
\text { Senvices }\end{array}$ & Manufacturing & Trade & $\begin{array}{c}\text { Business and Personal } \\
\text { Services }\end{array}$ \\
\hline \multicolumn{5}{|c|}{ Job has Lasted } \\
\hline 10-14 years & $\begin{array}{c}-\mathbf{0 . 0 3 2} \\
(0.641)\end{array}$ & $\begin{array}{l}-0.127 \\
(0.733)\end{array}$ & $\begin{array}{l}-1.067 \\
(0.671)\end{array}$ & $\begin{array}{c}1.663 \\
(0.702)^{* *}\end{array}$ \\
\hline 15-19 years & $\begin{array}{c}0.507 \\
(0.292) *\end{array}$ & $\begin{array}{c}-\mathbf{0 . 4 3 5} \\
(\mathbf{0 . 3 3 4})\end{array}$ & $\begin{array}{c}-\mathbf{0 . 6 0 7} \\
(\mathbf{0 . 4 1 0})\end{array}$ & $\begin{array}{l}-\mathbf{0 . 2 4 5} \\
(0.901)\end{array}$ \\
\hline 20-24 years & $\begin{array}{c}0.417 \\
(0.494)\end{array}$ & $\begin{array}{c}-0.759 \\
(0.316)^{* *}\end{array}$ & $\begin{array}{l}-0.729 \\
(0.614)\end{array}$ & $\begin{array}{c}0.293 \\
(1.017)\end{array}$ \\
\hline 25-29 years & $\begin{array}{c}\mathbf{0 . 2 4 4} \\
(\mathbf{0 . 7 2 3})\end{array}$ & $\begin{array}{l}-\mathbf{0 . 5 1 5} \\
(\mathbf{0 . 4 1 2})\end{array}$ & $\begin{array}{l}-0.648 \\
(0.648)\end{array}$ & $\begin{array}{l}1.367 \\
(1.704)\end{array}$ \\
\hline \multicolumn{5}{|c|}{$\begin{array}{l}* * * \text { significant at the } 1 \% \text { level } \\
* * \text { significant at the } 5 \% \text { level } \\
* \text { significant at the } 10 \% \text { level }\end{array}$} \\
\hline \multicolumn{5}{|c|}{$\begin{array}{l}\text { a) Trend coefficients from regression of dependant variables (168 monthly observations) upon monthly dummy variables, log } \\
\text { unemployment rate and a linear time trend. Coefficients represent average monthly change * } 1000 \text { over the period. Al } \\
\text { results are corrected for } \mathrm{AR}(1) \text {. }\end{array}$} \\
\hline
\end{tabular}




\section{Conclusion}

This paper examines changes in job stability over the period 1981 to 1994 . We do this by (1) examining changes in the complete length of new jobs and (2) looking directly at changes in the job survival function. Although the average complete length of new jobs showed no significant trend over the period, the distribution of complete new job lengths has shifted away from medium term jobs towards shorter term jobs. This means that new job holders are experiencing more instability at the end of the period than at the beginning. However, once the 6 month milestone has been passed, workers have enjoyed increasing job stability with the result that the proportion of long-term jobs has remained unchanged. This conclusion is in contrast to comparable studies done with U.S. data, but these studies were unable to examine changes in jobs less than 4 years in length.

This pattem of change persists when different demographic groups are studied. The probability that a new job would last beyond six months declined significantly while the probability that a 6 month old job would last beyond 5 years increased significantly or did not change for all sub-groups. This change represents a polarization of jobs for most Canadian workers. The only exceptions to this are job starters 45 years of age and over and job starters in Atlantic Canada where changes are better described as a shift towards more short-term jobs.

Despite the stability in the proportion of new jobs which last to become long-tem, there is some evidence that long lasting jobs held by older workers are at a higher risk of ending now than in the early 1980's. However, this decline is concentrated among older workers with high senionity which suggests it may be largely due to an increased prevalence for early retirement. In addition, there is evidence that long jobs held in the manufacturing and trade industries are less stable now than in the eary 1980s but these changes are small and offset by increased stability of long jobs in the service industries.

It remains to be explained what factors are driving these changes. Although this paper does not attempt to identify particular causes, the evidence suggests that the changes are being driven by economy wide factors. Overall these trends are consistent with other trends which have emerged in the economy including the rise in non-standard work, polarization of eamings and hours, and the increasing use by firms of a core of permanent employees. 


\section{Bibliography}

AKERLOF, George A. and Brian G. M. Main (1981). "An Experience-Weighted Measure of Employment and Unemployment Durations." American Economic Review, vol.71, pp.10031011.

BAKER, G.M. and P.K. Trivedi (1985). "Estimation of Unemployment Duration from Grouped Data: A Comparative Study." Journal of Labor Economics. Vol. 3, pp. 153-174.

BAKER, Michael (1992). "Unemployment Duration: Compositional Effects and Cyclical Variability." American Economic Review. Vol. 82, pp. 313-21.

CARLSON, John A. and Michael $W$. Honigan (1983). "Measures of Unemployment Duration as Guides to Research and Policy: Comment." American Economic Review, vol. 73, pp. 11431150.

CHRISTOFIDES, L. N. and C. J. McKenna (1993). "Employment Flows and Job Tenure in Canada." Canadian Public Policy. Vol. 19, pp.145-161.

CHRISTOFIDES, L. N. and C. J. McKenna (1995). Employment Patterns and Unemployment Insurance. Human Resources Development Canada.

CORAK, Miles (1993). "The Duration of Unemployment During Boom and Bust." Canadian Economic Observer. Statistics Canada Catalogue No. 11-010. (September), pp. 4.1-4.20.

CORAK, Miles and A. Heisz (1996). "Altemative Measures of the Average Duration of Unemployment." Review of Income and Wealth, vol 42, pp. 63-74.

DIEBOLD, Francis X., David Neumark and Daniel Polsky (1994). "Job Stability in the United States." National Bureau of Economic Research, Working Paper No. 4859.

DIEBOLD, Francis X., David Neumark and Daniel Polsky (1996). "Comment on Kenneth A. Swinnerton and Howard $W$ ial, 'Is Job Stability Declining in the U.S. Economy?'." Industrial and Labor Relations Review Vol. 49, pp. 348-352.

ECONOMIC COUNCIL OF CANADA (1991). Employment in the Service Economy. Minister of Supply and Services Canada.

FARBER, Henry S. (1995). “Are Lifetime Jobs Disappearing? Job Duration in the United States: 1973-1993." National Bureau of Economic Research, Working Paper No. 5014.

GREEN, David A. and $W$. Craig Riddell (1995). "Job Durations in Canada: Is Long Term Employment Declining?" Unpublished mimeo. University of British Columbia and Canadian Institute for Advanced Research. 
HALL, Robert E. (1982). "The Importance of Lifetime Jobs in the U.S. Economy." American Economic Review Vol. 72, pp. 716-24.

HASAN, Abrar, and P. de Broucker(1985). Unemployment, Employment, and Non-Participation in Canadian Labour Markets. Minister of Supply and Services Canada.

HEISZ, Andrew (1995). "The Changing Importance Of Lifetime Work in the Canadian Economy." Unpublished Mimeo. Business and Labour Market Analysis Division, Statistics Canada.

HEISZ, Andrew (1996). "Changes in Job Tenure in Canada." Canadian Economic Observer. Statistics Canada Catalogue No. 11-010. (January), pp. 3.1-3.9.

MORISSETTE, R., J. Myles and G. Picot (1993), “What is Happenning to Eamings Inequality in Canada." Analytical Studies Branch Research Paper No. 60, Statistics Canada.

OSBERG, L., F. Wein and J. Grude (1995). Vanishing Jobs, Canada s' Changing Workplace, James Lorimer \& Co.

PICOT, G., J. Myles and T. Wannell (1990). "Good Jobs/Bad Jobs and the Declining Middle: 19671986”, Analytical Studies Branch Research Paper No. 28, Statistics Canada.

SALANT, Stephen (1977). "Search Theory and Duration Data: A Theory of Sorts." Quarterly Journal of Economics. Vol. 91, pp. 39-57.

SIDER, Hal (1985). "Unemployment Duration and Incidence: 1968-82." American Economic Review. Vol. 75, pp. 461-72.

SWINNERTON, Kenneth A. and Howard Wial (1995). "Is Job Stability Declining in the U.S. Economy?" Industrial and Labor Relations Review Vol. 48, pp. 293-304.

SWINNERTON, Kenneth A. and Howard Wial (1996). "Is Job Stability Declining in the U.S. Economy? Reply to Diebold, Neumark, and Polsky" Industrial and Labor Relations Review Vol. 49, pp. 352-355.

STATISTICS CANADA (1992). Guide to Labour Force Survey Data. Catalogue Number 71-528.

URETA, Manuelita (1992). “The Importance of Lifetime Jobs in the U.S. Economy, Revisited." American Economic Review Vol. 82, pp. 322-34. 